Ks. GRZECORZ RÝ́

\title{
NARODOWE GLOSY KATECHIZMOWE ZESLAŃCA 1864 ROKU
}

\author{
„Miejcie nad-ieje, bo nadzicja przejdzie z ans do

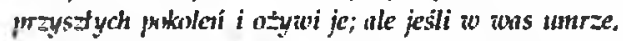 \\ to prayszte pokolenin begda $z$ litdzi martwych" \\ (J. Slowacki, Anhelli)
}

Archiwalia dokumentujące życie Polaków na Syberii, znajdujace się $w$ tobolskim oddziale Panstwowego Archiwum Województwa Tiumeńskiego, sa jak do tej pory, calkowicie nieznane polskim historykom. Niemal zupelnie nie wykorzystywali ich także historycy radzieccy i rosyjscy. Ostatnia, być może jedyna, praca poświęcona polskim zeslańcom oparta na żródlach tobolskich, ukazala się $w 1963$ roku$^{1}$. Jej autorzy wykorzystali jednak tylko ulamkowa liczbę (dokladnie 118) „spraw”, zaś dodany przez nich do uzyskanych danych komentarz - jaskrawa ilustracja minionego pólwiecza - jest bardziej ideologiczny niż krytyczny. Tymczasem, tylko jeden zbiór (fond) tobolskiego archiwum, oznaczony numerem 152, na który składaja się wylacznie polonica, obejmuje 2717 "diel" (pozostale rozrzucone sa po innych fondach). Większość z nich to osobiste teczki zeslaniców, a $w$ nich: historie zeslania, charakterystyki, świadectwa wystawiane przez miejscowe władze, okresowe opinie, wszystkie decyzje dotyczace danej osoby². Nie brak także cenniejszych jeszcze materiałów dokumentujacych życie codzienne "ssylnych": starania o zgode na powrót do $\mathrm{kraju}^{3}$, na wykonywanie zawodu czy

' Ucanstniki polskotwo ansstunija 1863-1864 88 w toholskoj ssyłkic. Pod red. D.I. Kopylowa. Tiumeń 1963.

2 Tobolskij Filial Gosarchiwa Tiumeńskoj Obłasti (GATO). Rkp. (bez sygn.): Dieło o politssylnym Witoldie Stankiewiczie, f. 152 op. $3 \mathrm{nr} 16$.

3 GATO Rkp. (bez sygn.): Dieto..., f. 152 op. 3 nr 186 i 191. 
rzemiosła ${ }^{4}$, próby sprowadzenia rodziny $z$ kraju ${ }^{5}$, czy zalożenia jej na zesłaniu, rewizjc, zakazy, racje żywnościowe, protokoly z badań lekarskich przeprowadzanych $w$ miejscowym więzieniu ${ }^{6}$, podania $w$ rozmaitych sprawach $\dot{z} y-$ ciowych ${ }^{7}$.

Dzięki tym dokumentom, występujace w policyjnych zestawieniach i same w sobie wymowne cyfry (od 1 stycznia 1863 do 31 grudnia 1866 roku przez Tobolsk przewinęlo się 18623 Polaków $\left.w^{b}\right)$, nabieraja życiowego i personalnego kolorytu, przybierają ksztalt konkretnych i żywych osób. Na szczególną uwage zasługują z pewnościa pamiątki literackie o najbardzicj osobistym, „nicurzędowym" charakterze, prywatne zapiski dokonywane tylko dla siebie, wspomnienia, refleksje, nie napiętnowane cenzura, ani nawet lękiem przed nią. Te najdoskonalej pozwalaja dotrzeć już nie tylko do losów zeslańców, ale także do ich wrażeń, uczuć, sposobu myślenia, świata wartości i przeżyć religijnych.

W tej wlaśnie grupie dokumentów niewatpliwie wyjątkowa i cenna relikwię stanowi ręcznie przepisany katechizm, związany z osoba Kazimierza Kurdwanowskiego - powstańca styczniowego, skazanego "na żytje” w Pietropawlowsku (okręg akmolinski w kirgiskim obwodzie ${ }^{9}$ ). Zachowane w archiwum tobolskim zestawienie "politssylnych" rozmieszczonych w tobolskiej guberni $z$ dnia 1 stycznia 1867 roku informuje, źe w Pietropawlowsku mieszkalo wtedy 34 zeslańców ${ }^{10}$. Kurdwanowski - pozostając pod nadzorem policji - wynajmował mieszkanie w domu Wyciżanina, dymisjonowanego urzędnika arsenału I klasy ${ }^{11}$. Są to, niestety, w zasadzie wszystkie pewne informacje na temat Kazimierza Kurdwanowskiego; reszty możemy się tylko

4 GATO Rkp. (bez sygn.): Dicło..., f. 152 op. 3 nr 35 (Zeslaniec stara się o zezwolenie na praktyke lekarską w Tobolsku).

5 GATO Rkp. (bez sygn.): Dieto..., f. 152 op. 3 nr 5.

6 Tamże, nr 10. Tobolskie wiezzienie - największe i najsurowsze w calej Zachodniej Syberii pelniło role "punktu przesylkowego": tu dostarczano większość zeslańców, i po 2-3 miesięcznym pobycie przesylano dalej. Więzienie, przeznaczone na 500 osób, niemal zawsze bylo przepelnione. Wiosna 1864 r. przebywalo w nim 1700 Polaków. W wiezieniu funkcjonowal szpital: jesienia 1864 roku znajdowalo się $w$ nim 250 Polaków chorych na tyfus. Pomocy udzielalo im dwóch lekarzyzeslańców: Ignacy Tomkowicz i Waclaw Lasocki. - Zob. Uczastniki..., s. 14-22.

7 GATO Rkp. (bez sygn.): Dicto..., f. 152 op. $3 \mathrm{nr} 190$.

8 Ulcastniki..., s. 13, por. D. Kopylow, I. Prybylskij, Tobolsk. Swierdlowsk 1975, s. 89.

9 E. Kaczyńska, Syberia - najuiększe zięzienie śwüta. Warszawa 1991, s. 314. - „Żytje” (zamieszkanie) stanowilo jeden z 4 rodzajów zeslanin (obok "posielienija”, "wodworienija" i katorgi). Odbywajacy tę

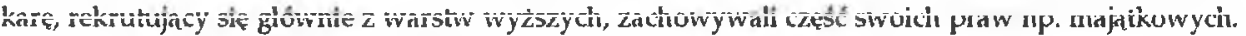
Podlegali wszakże nadzorowi policyjnemu i nie wolno im bylo opuszczać wyznaczonego miejsca zamieszkania. Paradoksalnie, niektórzy zeslańcy uważali ten rodzaj kary za cięższy od katorgi, która - choć wyczerpująca fizycznie - oznaczala jednakże pewny przydzial żywności i dacl nad glowa. Poza więzieniem możliwości zdobycia pracy, a co za tym idzie, podstawowych środków do życia, byly znikome. "Bliżej wolnemu na katorgę, niz katorżnikowi do wolności" - mawiano. Na ten temat zob. E. Kaczyńska, op. cit., s. 35-36 oraz 153-155; por. Ucznstniki.., s. 11-12.

10 GATO Rkp. (bez sygn.): Dieło..., f. 152 op 3 nr 96.

1) Tamze, nr 179 k. 1. 
z większą lub mniejsza pewnością domyślać na podstawie zachowanych akt sprawy, zatytulowanych „Dielo ob otobrani u politssylnowo Kazimira Kurdwanowskowo knigi Kratkij katiechizis dla molodych ludiej"12.

Dnia 11 grudnia 1867 roku w mieszkaniu Kurdwanowskiego zostala przeprowadzona rewizja. Dokonali jej pomocnik horodniczego (tzn. naczelnika miasta i policji) Gawriszenko-Skaleckij oraz pristaw (szef policji małego obszaru administracyjnego) Trusow. Wśród rzeczy osobistych zesłańca, papierów i książek nie znaleziono nic, czego posiadanie „jest zakazane przez prawo". Za to w sypialni, na holenderskim piecu wysokości 3,5 arszyna (ok. 2,5 m) policjanci znaleźli polską książkę pt. „Krótki Katechizm dla mlodzi Katolickiego Wyznania. Za naywyższym Rozkazem ułożony i wydrukowany w Wilnie 1855 roku". Przeszukującym wydało się podejrzane miejsce przechowywania książki, czego nie omieszkali odnotować $w$ sporządzonym tajnym raporcie: „Uznawszy, ze przechowywanie zwyklej książki na piecu o wysokości 3,5 arszyna, skad, żeby ja wziąć, należy za każdym razem użyć drabiny, jest niemożliwe, podejrzewaja, że książka ta zawiera treści niezgodne $z$ prawem, i była ukrywana na piecu na wypadek niespodziewanej rewizji"'l3. Niepokój policjantów dodatkowo powiekszal fakt. że książka - jak zaznaczylišmy na wstepie - nie była drukowana, lecz przepisana recznie przez Kurdwanowskiego z drukowanego oryginału ${ }^{14}$. W czasie wstępnego przesłuchania Polak stwierdzil, że „książka ta należy do niego, że przywiózł ją ze soba jeszcze z Rosji, w jego domu służyła do uczenia dzieci, a wziąl ją ze sobą, ponieważ spodziewal się, że dzieci przyjadą do niego na Sybir; ponadto sam ja czasami czytywal, ponieważ zawiera modlitwy; nie ukrywal jej, a na piecu znalazła się tam najprawdopodobniej dlatego, ze ktoś ja tam rzucil"15. Zeznania nie usatysfakcjonowaly policjantów. Książka została obwiązana szmurem i opieczętowana pieczęcią policyjna, imienna pristawa oraz pierścieniem Kurdwanowskiego (z wyry tymi literami WK), i wraz z protokołem podpisanym przez policjantów, wlaściciela domu oraz zesłańca, przekazana Pietropawłowskiej Policji Miejskiej ${ }^{16}$.

Następnego dnia, 12 grudnia, pomocnik pietropawłowskiego horodniczego Iwan Leontiew Gawriszenko-Skaleckij dokonal przeglądu Katechizmu, a przede wszystkim uzupelniających go modlitw (gdyż jak stwierdzil, „dogmatyka tego wyznania nie byla mu znana"17), zaznaczając olówkiem na marginesach i tłumacząc na język rosyjski fragmenty, które uznał za nieprawomyślne ${ }^{18}$.

12 Tamże.

13 Tamże, k. 3.

14 Mimo usilnej kwerendy autorowi nie udalo się dotrzeć do drukowanego pierwowzoru. Wydaje się, że mógł nim być Krótki kntechizm dla młodzi rzymsko-kntolickiego ioyzuanin, uczqcej się w natkowych zaktadach w Rossyi, za najuyższym rozkazem ujożony $i$ wydrukoivany. Wilno 1834.

15 GATO Rkp. (bez sygn.): Diefo..., f. 152 op. 3 nr 179 k. 1 i 3.

16 Tamże, k. 6 i 7.

17 Tamże, k. 4.

18 Tamże, k. 4-5. 
Dnia 19 grudnia książka wraz z raportem, protokolem z przesluchania i omówieniem dokonanym przez Gawriszenkę-Skaleckiego, zostala przeslana do Naczelnika Gubernialnego Wydzialu żandarmerii w Tobolsku z prośba "o powiadomienie, czy $w$ ksiażce tej zawarte sa treści zakazane przez prawo i antypaństwowe, oraz czy jej wlaściciel, wyżej wspomniany Kazimierz Kurdwanowski, podlega za jej posiadanie ściganiu"19.

Odpowiedź zostala wystawiona dopiero po uplywie 6 miesięcy - 16 czerwca 1868 roku. Naczelnik dopatrzyl się w książce „kilku stwierdzeń o cechach wykroczenia natury politycznej". Za groźne uznal nie tylko to, co zostało w ksiażce zapisane, ale i także to, co zostalo świadomie pominięte: "Nigdzie w calym katechiźmie nie wspomina się o posłuszenistwie wobec monarchy i wladzy". Naczelnik nakazal wzmocnić nadzór policyjny nad Kurdwanowskim, "ze względu na wplyw, jaki może on wywierać na innych zeslańców politycznych"20. Książka zostala zarekwirowana.

Przechowana w Tobolskim archiwum stanowi niezwykle ciekawe źródlo do poznania religijności polskich zesłańców, religijności ksztal towanej $w$ drastycznie ciężkich warunkach życiowych, w sytuacji oddalenia od kraju i rodziny, $w$ codziennej polemice $z$ rozpacza, a także - rzecz niebagatelna przecież - w calkowitej niemal niemożności dotarcia do księdza i zwyklych aktów pobożności ${ }^{21}$. Nie jest to wprawdzie pamiętnik; nie jest to także $w$ pelni oryginalne dzieło zesłańca, lecz wlasnoręcznie przezeń przepisana kopia drukowanej książki. Niemniej, Kurdwanowski nie poprzestał na roli biernego kopisty. Drukowany katechizm uzupelnił własna, licząca osiem stron przedmowa, skierowana bezpośrednio do swoich dzieci, a także zbiorem modlitw codziennych, oraz osobistymi uwagami i "dodatkami" w samym tekście katechizmu. Nawet bez konfrontacji $z$ oryginalem można je $z$ duża doza prawdopodobieństwa wskazać jako te, którym nie byłoby dane umknąć uwagi nawet najbardziej leniwego cenzora.

Te właśnie, "odautorskie"uzupelnienia Kurdwanowskiego moga nam wiele powiedzieć o nim samym, o jego świecie wartości i o nadziei, która wiązal $\mathrm{z}$ wiara. Niezwykle wymowny jest już fakt, że wyruszając na zesłanie, zabral ze soba katechizm jako rzecz absolutnie niezbędna ${ }^{22}$ : "spodziewal się bowiem, że dzieci przyjada do niego na Sybir". Dla Kurdwanowskiego - ojca rodziny

in Tamże, k. 9.

20 Tamże, k. 10 i 11.

21 W latach 1865-1870 wszystkich nieomal duchownych zeslanych na Syberie przemieszczono do Tunki (k. Irkucka) w celu odizolowania ich od pozostalych zeslańców - na ten temat zob. K. Sowa, Losy duchowienistiva polskiego zestnnego un syberię po powstaniu stycunion'ym (1863-1883). „Nasza Przeszlość" 77:1992, s. 123-163, por. M. Janik, Dzieje Polnków u Syberii. Kraków 1928, s. 333-344.

22 Trzeba pamiętać, że waga bagażu zeslańca nie mogla przekraczać 30 funtów - zob. Uczestniki., s. 20 . 
glównym celem religii bylo wychowanie czlowieka. W przedmowie adresowanej do dzieci, napisal: „Kochane Dziatki. Pierwsza zasada moralnego życia czlowieka jest Religia - bez niey czlowiek jest gorzey zwierzęcia, bo i naydzikszy, naydrapieżnieyszy zwierz czci Boga, i pelni obowiązi na niego przez Boga wlożone - Niedźwiedzie, Wilki, Tygrysy, sa dla bliźnich swoich, drugich Niedźwiedzi, Wilków, Tygrysów, z przychylnościa i milościa $=$ Religia czegóż innego naucza jak czci dla Boga i milości bliźniego $=\mathrm{W}$ tey milości bliźniego zwierzęta zachowuja stopniowanie. Dzieci Niedźwiedzi, Wilków, Tygrysów więcey kochają swoich Rodziców, a Rodzice swoje dziatki, aniżeli innych Niedźwiedzi, Wilków, Tygrysów - W Religii toż samo jest Prawo $=W$ Dziesięcioro Przykazania, pierwsze trzy nakazują nam cześć Bogu i posluszeństwo prawom Jego, następuje zaraz Przykazanie czwarte: Czciy Oyca i Matke twoja, jako Rodzice zaraz po Bogu najpierwsza milość i cześć mieć powinni - Dalsze przykazania wskazuja Czlowiekowi jego obowiązki wzglẹdem innych ludzi (...) Z przekonania sumiennego o konieczney potrzebie dla Was tey nauki, podjalem prace przepisania jey dla Was, abyście zasady moralności i Obowiązków czlowieka mogli się uczyć. Uczcie się więc, Dziatki Kochane, a przy tem pamiętaycie, że Religia nie poprzestaje na tem, aby tylko czytać lub wyuczyć się na pamięć Ksiag Religii nauczajacych, aby klepać pacierze, $i$ to jest potrzebne, ale nie jest jeszcze wypelnieniem Celu Religii = Religia bowiem, zasadza się na dobrych uczynkach, do których dziecko od naymnieyszego wieku powinno zaczynać się wprawiać, bo jak $w$ dobrym, tak i $w$ zlym, czlowiek $w$ dzieciństwie od malego poczyna i postepujac coraz daley $w$ lata, postępuje $w$ cnotach lub wystepkach, $i$ doyrzalym wieku staje sie zacnym, poczciwym Czlowiekiem, lubionym i szanowanym przez Wszystkich, lub wielkim zbrodniarzem"23.

Nawet na zesłaniu nie stracil Kurdwanowski wiary, że $w$ religii kryje się immanentna moc przeksztalcania wzajemnych międzyludzkich odniesień i tworzenia nowego, lepszego świata: „Albowiem skoro tylko tobie wzbroniono jest, i Ty nie czynisz takiego, coby bylo z krzywda bliźniego Twego, a co możesz robisz dobrego dla drugich = Też same Obowiązki Religia nie tobie tylko przypisuje, ale wszystkim ludziom, więc drudzy ludzie na zasadzie teyże samey Religii musza wystrzegać się szkodzić w czem kolwiek tobie, i maja Obowiązek nieść Ci pomoc, a następnie i Tobie z tym dobrze, że ciẹ nikt nie skrzywdzi - a ktoś w potrzebie pomoźe i życzliwość swoja ci okaże. Taki jest Cel Religii przez Boga nam przypisany"24.

Jeśli szukać powodów, dla których ten cel religii - tworzenie bliskich więzi miédzy ludźmi - wciąż jeszcze pozostaje nie zrealizowany, to można je odnaleźć w nieumiejętnym wychowywaniu dzieci: „Male zlego poczatki pro-

23 GATO Rkp. (bez sygn.): Dido..., f. 152 op. 3 n 179 Krofti Katechizm, s. 16.

24 Tambe, s. 3. 
wadza do wielkich zbrodni - Niech tylko Dziecko będzie nieposłuszne Rodzicom, Niech przed niemi ukrywa się ze swojemy czynnościami - niech nauczy się klamać - niech nie ma dla Rodziców prawdziwego, z calego serca przywiazania i poszanowania, takie dziecko niezawodnie wyrośnie na wielkiego zbrodniarza, dla takiego $w$ pełnoletniości latwo będzie kraść, rozbijać i zdradzać = Jeżeli dziecko $w$ młodocianych latach nie kocha swoich Rodziców i Rodzeństwa swego (...) takie za przyjściem do pelnoletniości nie może kochać swojey Oyczyzny, a następnie dostapi naywiększey w świecie zbrodni, bo gotów stać się zdrayca własney Oyczyzny i własnych Rodziców zdradzać, a to jest nywiększa w świecie zbrodnia, na która ziemia się wdryga"25.

Wydaje się, że te fragmenty, zaczerpnięte - powtórzmy - z odautorskiej przemowy Kurdwanowskiego, wyraźaja jego glówna myśl dotyczaca wiary i wychowania religijnego: prawdziwa wiara wypowiada się przez cnotę tzn. szereg właściwych postaw moralnych, spośród zaś wszystkich cnót najwyższą jest umilowanie Ojczyzny. Takie myślenie towarzyszyło Kurdwanowskiemu w całej pracy przepisywania "Krótkiego Katechizmu", dyktujac mu konieczne uzupelnienia, przeksztalcenia i akcenty. W 5-tym rozdziale ${ }^{26}$, zatytulowanym "O Prawości chrześcijańskiey", po omówieniu czterech cnót kardynalnych Kurdwanowski zamieszcza wyraźnie osobistą refleksję:

„P(ytanie): Jakie sa jeszcze cnoty moralne -

O(dpowiedź): Wszystkich cnót moralnych trudno jest wyliczyć. Kaźde zdarzenie wywoluje nowa cnote - Wszakże pomianuje tu niektóre - Naypierwsza jest milość Oyczyzny nieograniczona ze wszelkim poświęceniem"27. Także wcześniej, w rozdziale 3-cim, omawıając najważniejsze przykazanie miłości Boga i bliźniego, Kurdwanowski uzupel nia oficjalną - drukowana wersję:

"P. A co do bliźnich -

O. Powinniśmy kochać bliźniego swego jak siebie Samego, to się ogólnie mówi do Ludzi, lecz tu sa jeszcze Wyższe uczucia Milości = Milość Rodziców, Miłość Rodzeństwa, Miłość Rodaków, a za nimi Naywyższa Miłość Oyczyzny, bo dla tey miłości jest siebie poświęcić Chrześcijanin obowiązany"28.

"Naywyższa Milość Oyczyzny" wyraża się, wedle Kurdwanowskiego szeregiem bardzo konkretnych postaw: chrześcijanin powinien modlić się "za Rodaków" ${ }^{29}$, a w codziennym rachunku sumienia winien sobie zadać pytanie: "Czyśmy wypelnili Obowiazki względem Rodziny, Rodaków i Oyczyzny, jak

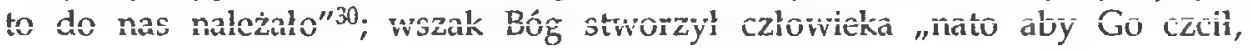

25 Tamże, s. 6-8.

26 Katechizm podzielony jest na pięć rozdziałów: 1. O wierze; 2 . O nadziei; 3 . O milości; 4. O sakramentach; 5 . O sprawiedliwości chrześcijańskiej.

27 GATO Rkp. (bez sygn.): Dieło..., f. 152 op. 3 nr 179; Krótki Kntechizm..., s. 87.

28 Tamże, s. 43.

29 Tamże, s. 41.

30 Tamże, s. 66. 
wiernie Mu służył, był pożyteczny Ludziom i Oyczyźnie" ${ }^{31}$. W 4-tym dziale "Katechizmu”, na pytanie: „Co to jest sakrament małżeństwa?", Kurdwanowski odpowiada: "Sakrament Małżeństwa jest nierozerwane polączenie dwóch Osób Mężczyzny i Niewiasty wkładające na nich Obowiazek żyć z soba razem aż do śmierci po Chrześcijańsku w Miłości i zgodzie i wychowywania swych Dzieci w bojaźni boskiej i Miłości Oyczyzny"3?.

Oczywiście, wszystkie cytowane wyżej fragmenty zostaly wychwycone przez policyjnego cenzora, który zaznaczyl je wyraźnie na marginesie książki. Nie uszlo też jego uwagi znajdujace się w katalogu uczynków miłosiernych co do ciala - przepisane czy też lekko "przeinterpretowane" przez Kurdwanowskiego? - wskazanie: „Więźniów starać się uwolnić”33. Naczelnik tobolskiej żandarmerii natomiast $w$ wydanym przez siebie orzeczeniu zareagował bardzo ostro na znów niewątpliwie „uzupełnioną" przez Kurdwanowskiego refleksje nad męka i śmiercią Chrystusa:

„P. Dlaczego Piłat na tak ciężką karę wskazał Chrystusa?

O. Bo w oczach Zaborców nie ma większego Zbrodniarza, jak ten, który zamyślał wyswobodzić z pod ich władzy kray przez nich zagrabiony; Złodziey, Zboyca muiey sa wimi wich oczach" 34 .

Nie jedyne to miejsce, w którym Zesłaniec odmalowuje analogię między sytuacja Polski, a historią biblijnego Izraela. Po omówieniu 10 Przykazań, Kurdwanowski zadaje pytanie o wlaściwe zrozumienie sensu znajdującego się w Biblii wprowadzenia do nich: "Ja jestem Pan, twój Bóg, którym cię wywiódł z ziemi egipskiej, z domu niewoli” (por. Wj 20,2) i odpowiada: „Tu Bóg Objawil, że On jest Bogiem Człowieka, Który uczynił temu Ludowi naywyższe Dobrodzieystwo i wyswobodzil go z Obcey Niewoli, co jest naywiększym Ludu nieszczęściem"35.

Oczywiście, nie cały „Katechizm” poświęcony jest Ojczyźnie i obowiązkom względem niej; jest on przecież prezentacją wszystkich prawd wiary. Niemniej wydaje się, że przytoczone wyżej fragmenty miały szczególne znaczenie dla Kazimierza Kurdwanowskiego. Świadczy o tym zbiór modlitw, jaki dołączył do przepisywanego oryginalu. Nie ma wśród nich ani jednej, w której by zabrakło prośby w intencjach kraju i rodaków. W "Modlitwie Porannej" modlił się: „Boże Miłościwy! W Tobie jedyna nadzieja uszczęśliwienia naszego = Wybaw nas z mocy nieprzyjaciół naszych - wyzwól nas z niewoli (...) I za współbraćmi mojemi blagam Cię, Panie - Wybaw Dręczonych w więzieniach i prześladowanych za Sprawę Oyczysta”36. W „Modlitwie wie-

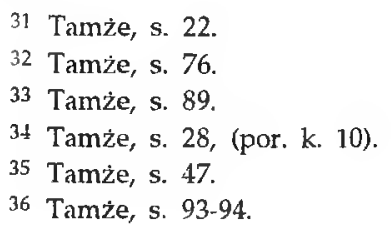


czornej” prosil zaś: „Wybaw Oyczyznę naszą z mocy nieprzyjaciół naszych Daj nam zgodę i jedność. Abyśmy Cię jednomyślnie Czcili i gotosvi byli do poświęceń nie tylko życia i majątków, ale i miłości wlasney dla dobra Oyczyzny naszey i Rodaków naszych"37. Modlitwe "Za Rodzinę" Kurdwanowski kończy prośbą o „szczęście Oglądania Oyczyzny naszey wyswobodzoney z mocy nieprzyjaciól naszych - Amen"38, zaś "Modlitwe do Trójcy przenayświętszey" zamyka postanowieniem: "Chcę pracować szczerze na Chwałę Twoja na mojey Oyczyzny i na Rodaków dobro - Pragnę z nieskazitelną sumiennością wszystkie Obowiązki względem Oyczyzny, Rodziny i Rodaków moich wykonywać - Amen"39. Modlitwa do Jezusa Chrystusa warta jest przytoczenia $w$ calości:

„O Panie Jezu Chryste Oycze Nasz Którego miłosierdzie Czuwa nad wszystkimi Ludźmi, Który dla zbawienia Ludu Twojego poświęciłeś się na śmierć męczeńską dając nam przykład i naukę jak powinniśmy każdey chwili gotowymi być do poświęceń dla zbawienia Ludu naszego - Widzisz O Panie nasze ciężkie Krzywdy - Zdzierstwa - rabunki - Grabieże - morderstwa. Dzikie pastwienie się nad nami Zaborców Oyczyzny naszey. Ze Izami wolamy do Miłosierdzia Twojego Panie - Wybaw nas z mocy nieprzyjaciół naszych i nie opuszczay Twojego Ludu, który już tyle męczeństwa poniósł dla zbawienia Swojego jako jesteś jego Panem i Oycem po wieki nieskończone Pokąd zaś milosierdzie Twoje Boskie nad n(ami) nie ustąpi u(twierdź) w nas Ducha wytrwałości, abyś my mężnie znosili cierpienia i nie ustawali w Milości Oyczyzny. Amen"t0.

Drugorzędną zupełnie sprawą jest, czy Kurdwanowski odpisal jedynie powyższe modlitwy ze znanego sobie zbioru, czy też sam w jakiejś mierze był ich autorem. Już sam ich wybór, a także głęboko osobista wewnętrznie zobowiązujaca nuta, wicle mówią o tym, w jaki sposób doświadczal swojego chrześcijaństwa. Miało go ono chronić przed utrata wiary w wyznawane przed zeslaniem wartości, nadać sens krzyża już przebytym i ciągle nowym cierpieniom, dostarczyć sił i nadziei. To już nie Kurdwanowski - ojciec i wspólautor Katechizmu, upatrujący w religii najlepszego narzędzia do wychowywania swych dzieci, wypowiada się przez te teksty, ale przeżywający wiarę osobiście - samotny człowiek postawiony przed niezwykle ciężka próbą warunków życia - wydawałoby się - zwalniających go ze wszystkich dotychczasowych ideaiów ludizkich i patriôtycznych.

Trudno jest podsumować omawiana, z konieczności fragmentarycznie, treść syberyjskiego „Katechizmu”. Trudno, z racji na towarzysząca świadomość, że jakiekolwiek oceny w tym względzie będa dotyczyć w równej mierze książki,

37 Tamże, s. 95-96.

38 Tamże, s. 99, (takie samo wezwanie kończy "Modlitwę do Matki Boskiej” - s. 109).

39 Tamze, s. 102.

40 Tamże, s. 103-104. 
co życia jej autora. Nie teologiczna, wyważona refleksja przecież, ale właśnie konkretne życie ojca rodziny i powstańca, stanowiace fragment calej heroicznej i tragicznej zarazem historii Polaków XIX w., wypowiedziało się na kartach tej książki. Wydaje się, że najlepsze podsumowanie moga stanowić slowa wspólczesnego polskiego Filozofa: "Religijność polska, jak wiemy, nie wytworzyla $w$ ciagu swej historii żadnego systemu teologii, który mógłby być wyrazem jej wewnętrznej prawdy. Mimo to, polskie chrześcijaństwo okazalo się $w$ krytycznych dla narodu czasach niewyczerpanym źródlem duchowych mocy, dzięki którym możliwe było dalsze trwanie narodu i jego walka o narodową tożsamość (...) Skazana na codzienna polemikę z rozpacza, wiara religijna oglądala swą wewnętrzną prawdę nie tyle w systemach teologii, ile $w$ konkretnej ludzkiej nadziei - nadziei, która raz po raz owocowała wielkim narodowym męczeństwem" ${ }^{41}$. Wlaśnie, konkretna ludzka nadzieja Kazimierz Kurdwanowski.

4 J. Tischner, Natziejn szuknjaca prazody. W: Cżtoiviek io nauce auspótczesuej. Rozmowy w Castelgandolfo - 1983. Paryż 1988, s. 101. 